\title{
Correction to: Neuropathology of multiple system atrophy: Kurt Jellinger’s legacy
}

\author{
Nicole Campese ${ }^{1,2}$ - Alessandra Fanciulli ${ }^{2}$. Nadia Stefanova ${ }^{2}$. Johannes Haybaeck ${ }^{3,4}$. Stefan Kiechl ${ }^{2}$. \\ Gregor K. Wenning ${ }^{2}$
}

Published online: 8 September 2021

(c) The Author(s) 2021

\section{Correction to: Journal of Neural Transmission https://doi.org/10.1007/s00702-021-02383-3}

In the original version of this article there was a mistake in reporting some references. The correct information is given below.

In section "Dissection of lesions and clinical correlates", in the fourth sentence of the first paragraph, the reference "Hwang et al. 2019" is not pertinent. The correct sentence should read:

In Japanese natives, SND was found in $18 \%$ and OPCA in $40 \%$ of MSA patients, with $42 \%$ of patients showing SND and OPCA co-pathology (Ozawa et al. 2010).

In section "Concomitant pathologies", fourth paragraph should read:

TAR DNA-binding protein of $43 \mathrm{kDa}$ (TDP-43) related pathology is rare in MSA and mostly occurs in the medial temporal lobe (Geser et al. 2011; Koga et al. 2018).

The original article can be found online at https://doi.org/10.1007/ s00702-021-02383-3.

\section{Gregor K. Wenning}

gregor.wenning@i-med.ac.at

1 Neurology Unit, Department of Clinical and Experimental Medicine, University of Pisa, Via Roma 67, 56126 Pisa, Italy

2 Department of Neurology, Medical University of Innsbruck, Anichstrasse 35, 6020 Innsbruck, Austria

3 Institute of Pathology, Neuropathology and Molecular Pathology, Medical University of Innsbruck, Müllerstrasse 44, 6020 Innsbruck, Austria

4 Diagnostic \& Research Center for Molecular BioMedicine, Institute of Pathology, Medical University Graz, Neue Stiftingtalstrasse 6, $8010 \mathrm{Graz}$, Austria
Similarly, FUS-related pathology is typically not detected in MSA (Geser et al. 2011).

The authors apologize for this errors, which do not impact on the scientific content of the paper.

Open Access This article is licensed under a Creative Commons Attribution 4.0 International License, which permits use, sharing, adaptation, distribution and reproduction in any medium or format, as long as you give appropriate credit to the original author(s) and the source, provide a link to the Creative Commons licence, and indicate if changes were made. The images or other third party material in this article are included in the article's Creative Commons licence, unless indicated otherwise in a credit line to the material. If material is not included in the article's Creative Commons licence and your intended use is not permitted by statutory regulation or exceeds the permitted use, you will need to obtain permission directly from the copyright holder. To view a copy of this licence, visit http://creativecommons.org/licenses/by/4.0/.

\section{Reference}

Geser F, Malunda JA, Hurtig HI, Duda JE, Wenning GK, Gilman S, Low PA, Lee VM, Trojanowski JQ (2011) TDP-43 pathology occurs infrequently in multiple system atrophy. Neuropathol Appl Neurobiol 37(4):358-365. https://doi.org/10.1111/j.1365-2990. 2010.01136.x (PMID:20942898;PMCID:PMC3030620)

Publisher's Note Springer Nature remains neutral with regard to jurisdictional claims in published maps and institutional affiliations. 